\title{
Integral indicator for evaluating system of material motivation employees of state and private enterprises in the construction sector
}

\author{
Natalia Zotkina, ${ }^{1, *}$, Sergei Bardasov ${ }^{2}$, Miroslava Gusarova, ${ }^{2,1}$, Anna Kopytova ${ }^{1}$ \\ ${ }^{1}$ Tyumen Industrial University, Volodarskogo str., 38, Tyumen, 625000, Russia \\ ${ }^{2}$ Tyumen State University, Volodarskogo str., 6, Tyumen, 625001, Russia
}

\begin{abstract}
The article is devoted to modeling mechanism for evaluation the labor contribution of Russian employees of public and private enterprises in the construction sector based on an analysis of current problems in the remuneration of the government. There was also taken into account the state of motivation system and job satisfaction of human resources in the executive authorities in the subject of Russian Federation (on an example of the Yamalo-Nenets Autonomous Okrug - YaNAO). The survey was dedicated to revealing preferences of civil servants in matters of career growth, professional development. On the basis of the quota survey of civil servants using absentee (dispenser) survey, conducted in July-September 2015 in Yamalo-Nenets, the following conclusions were formulated. The study has found that enrollment in the personnel reserve is not an effective measure to motivate public servants since it functions mostly just formally. Of particular importance are such working conditions as "remuneration dependence on the actual results" and "Personal responsibility for specific areas of activity", which is directly linked with the possibility to receive appropriate remuneration. Authors propose an integral indicator for assessing labor contribution of an employee of public and private enterprises of the construction sector in order to improve financial motivation and increase the level of interest, which is based on the principles of economic and mathematical modeling.
\end{abstract}

\section{Introduction}

According to the decree of the Russian President Vladimir Putin current trends in the reform and development of the civil service in Russia were identified. Among the main directions there were declared establishment of a special remuneration order based on achievement of performance indicators in professional activity. The most urgent need is to establish an efficient system of evaluating professional work performance of civil servants, which will link the achievements of employees and their wages, taking into account, first and foremost, the principle of fairness in wages.

The problem of forming the system of motivation and evaluation of a civil servant working in the Russian Federation is considered widely and presented to the scientific

*Corresponding author: zotkina 56@mail.ru 
community by the following scientists: G. Armashova-Telnik, E. Vasilyeva, E. Gorshkova, N. Zakharov, A. Muhametgalieva, Z. Pashayeva S. Kalabekova etc.[1, 3, 8, 10, 11, 12, 13, 15,] They explore the factors and methods to assess labor contribution of civil servants. There was examined the state of incentive system, its problems at the present stage of social development, identified the main challenges and contradictions that have direct impact on the formation of an adequate incentive system.

However, for the public service the issue of linking labor input evaluation with its reward remains undeveloped. There are problems related to civil servants labor characteristic, with the formation of salaries, which has a strict legislative framework. But, in accordance with the decrees of the President of Russia it is necessary to seek ways of improving the system of remuneration. In this regard, the aim of this study is to create an efficiency appraisal system for civil servants, which reflects the most significant contribution to their work and determines the most objective and reasonable bonuses.

\section{Methodology}

Methods of present study were to conduct a questionnaire survey of public servants to identify the most important aspects of motivation and to analyse regulations and practical approaches to the implementation the decrees of the President in this area [27, 29].

In order to study the state of motivation and formation of directions of personnel policy of public authorities system in accordance with the presidential decree there was carried out case study in the Yamalo-Nenets Autonomous District (hereinafter - YaNAO) on the basis of sample survey, which quota sample was as follows: civil servants 'leaders' category - 188 respondents, the survey was conducted by correspondence (dispenser) survey. The survey of civil servants was conducted among 34 executive bodies of state power. Sampling persons replacing posts of state civil service "leaders" category amounted to 324 respondents. The survey polled government employees of structural subdivisions of executive bodies of state power in subjects of Russian Federation. The result of the survey was identifying problems of motivation and suggesting ways to improve it in YaNAO. The analysis has categories "Head" and "specialist". Describing the overall gender composition of heads of services, it should be noted that men and women are present in the civil service in approximately equal proportions of 55\% women, 47 men. However, in the category of "specialist" male to female ratio is $31 \%$ and $69 \%$, respectively. Considering employees according to the length of their service, we can note the following tendencies reflected in Figures 1 and 2.

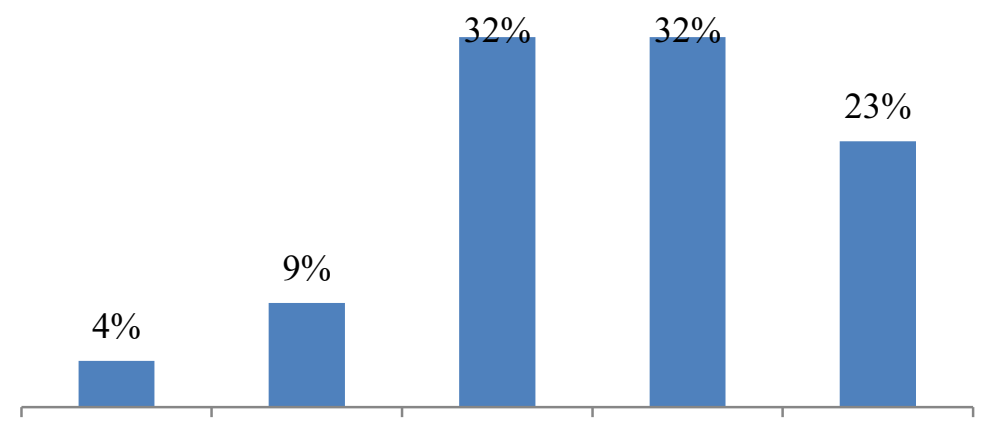

Up to 5 years From 5 to 10 From 10 to From 15 to More than 20 15 20

Fig. 1.The composition of the civil servants of the category "manager" according to length of service. 


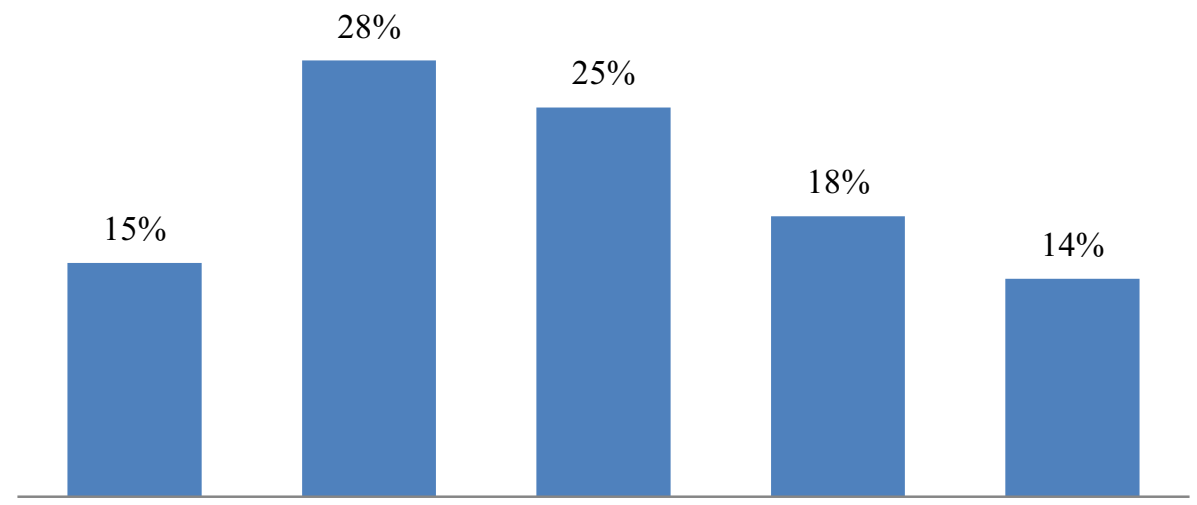

Up to 5 years From 5 to 10 From 10 to 15 From 15 to 20 More than 20

Fig. 2. The composition of the civil servants categories "specialist" according to length of service.

The most represented group consists of employees with experience from 5 to 10 years $(28 \%)$ and from 10 to 15 years $(25 \%)$. It says that more than half of the staff specialists have work experience of 10 years.

The share of the age group of 30 to 40 years old and from 40 to 50 years old people accounts $80 \%$ of managers ( $41 \%$ and $39 \%$, respectively). Young people under 30 years are present in the amount of $1 \%$, the rest is given to the heads in the age of over 50 years.

Analysis of civil servants in the category "specialist" according to the age showed that civil service positions are mainly occupied by middle-aged people from 30 to 40 and from 40 to 50 years, representing respectively $44 \%$ and $29 \%$. The share of employees up to 30 years and over 50 years accounts for approximately the same number - 12 and $15 \%$.

The most representative groups are from 10 to 15 years and 15-20 years length of service, the group with the experience of 20 years has $23 \%$. This demonstrates the high qualification of civil servants, but the low share of employees with the experience under 10 years $(13 \%$ in total) indicates weak inflow of young people in public authorities.

The educational structure of employees in both categories in the executive bodies of state power (Figures 3-4) in the context of education levels indicates the presence of all those surveyed higher education. At the same time, the leading share in the "Head" category assigned to have a specialist degree $(85 \%)$. Having Bachelor degree is declared by $4 \%$ of respondents and Master degree by $11 \%$.

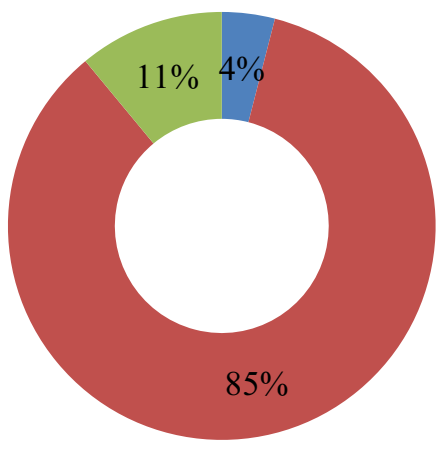

Baccalaureate

- Specialty

- Master's Courses

Fig.3. Education of civil servants in "Head" category. 
In addition, the survey found that $2 \%$ of managers on a state civil service have a $\mathrm{PhD}$, and $5 \%$ are candidates of sciences.

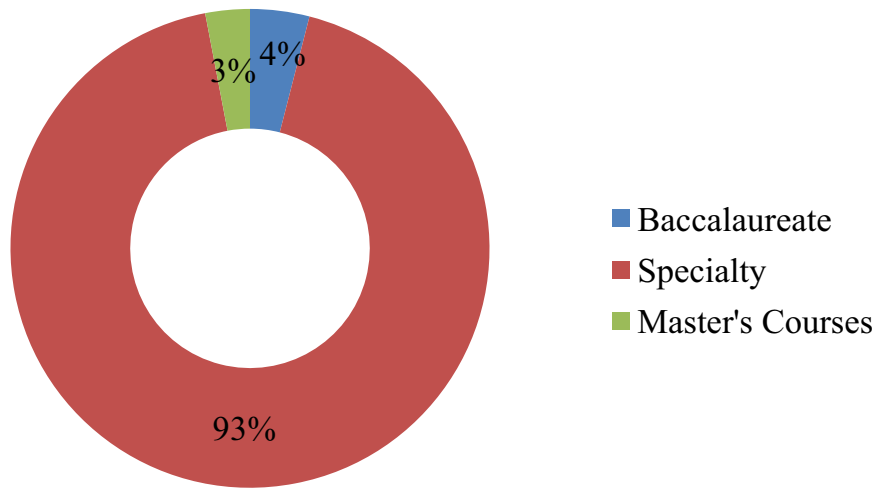

Fig. 4.Education of state civil servants in the "specialist" category.

Almost $93 \%$ of employees have higher education with "specialist" degree, a small number is given to bachelor and master degree (4\% and 3\%). Among experts there is $6 \%$ employees with $\mathrm{PhD}$ degree.

Respondents of the survey were asked series of questions about their motivation in accordance with the methodology. Thus, analyzing the answers to the evaluation of the factor "working conditions" in the group "Heads", it was found that the most popular answers were "dependence of remuneration on the actual results" and "Personal responsibility for a particular area of activity" (average score - 5) .In group with an average score of 4 werefollowing answers:

- Logistical support in the workplace;

- Regulated mechanism of career development;

- Professionallevelofcolleagues;

- Instituteofdisciplinaryliability;

- Moral and psychological climate in the team.

Average score of 3 points received:

- Having additional functions and responsibilities;

- Overtimework.

In the responses of "specialists" the factor "working conditions" was interpreted as follows (Table 1).

Table 1.Assessment of the factor "working conditions" by the civil servants in the "specialists" category.

\begin{tabular}{|c|ll|}
\hline Rating score & \multicolumn{1}{|c|}{ Factor (condition) of labor } \\
\hline I & 1. & Dependence of remuneration on actual results \\
& 2. & Personal responsibility for specific activities \\
\hline II & 1. & The moral and psychological climate in the team \\
\hline & 1. & Logisticalsupportofworkplace \\
III & 2. & Regulated mechanism for career development \\
& 3. & Professionallevelofcolleagues \\
& 4. & Instituteofdisciplinaryliability \\
\hline IV & 1. & Havingadditionalfunctionalresponsibilities \\
\hline V & 1. & Overtimework \\
\hline
\end{tabular}

Exploring the factors of motivation on the principles of their separation on internal and external components and their influence on the efficiency of labor, we can find out that 
managers and specialists attached great importance to such factor of internal motivation as personal responsibility for a particular activity. External factors that are important for managers are conditions of workplace, regulated by the order of official promotion, presence of the institute disciplinary liability. Specialists have identified in this group of factors dependence of wages from actual results and moral and psychological climate.

Assessing the impact of financial incentives has shown that the most preferred for the heads are flexible allowances for special working conditions of public service and award for results of work. For specialists the main measure of increasing the motivation is flexible allowance for special public service conditions and award in a fixed volume, along with the award, which is set by the individual leader for results of work.

In the non-financial group with a significant number of incentives the managers have mentioned such effective measures as encouragement with departmental awards, commendation at general meetings. Specialists mentioned to be important above mentioned, inclusion in the personnel reserve, ability to study.

It should be added that in a survey study we have revealed such weak motivators as: ideology, self-realization. They require additional activation and implementation of modern methods of motivation, among them introduction of various professional skills contests, system of intangible incentives.

General survey findings. The absence of a single integrated system of incentives for civil servants creates inequality of application of similar incentives in various government agencies. We have revealed following problems in material incentives for civil servants: blur criteria of compensation amount for execution of critical and complex tasks, weak motivating character of guaranteed monthly encouragement. In this case, the one and only stimulating award is surcharge for special conditions of civil service, which has just a compensatory character. However, public bodies have no uniform approach to its establishment: There are quarterly bonuses for successful activities and annual bonuses. In connection with the identified problems, there is required introduction of flexible systems for individual and collective bonuses $[4,5,9,14,17,18]$. In order for staff to influence the size of its cash allowance, you must define these performance indicators, which would most reflect the "degree of involvement and contribution" of a particular public servant. In addition, the development of clear scale of indicators will reduce the impact of interpersonal relationships on the distribution of rewards, as well as partially solve the problem of frequent change of goals and objectives by the managers.

Summarizing all the identified problems, given their systemic nature, which occurs in almost all bodies of Russian authorities, complexity of identifying indicators of labor efficiency, by analyzing the embedded methods of assessing labor contribution of civil servant, we have proposed fundamental mechanism for assessing labor contribution of civil servants in order to improve financial motivation and increase the level of interest.

\section{The results obtained in the study}

On the basis of international experience we have scientifically identified main groups and types of indicators, as well as the main approaches to their formation $[1,2,3,15,16,19$, $20,21,22,23,24,26]$.

As a result, performance indicators were divided into following groups:

- Process indicators or indicators characterizing fulfillment of duties, administrative and official regulations by civil servants;

- Direct outcome indicators or indicators that characterize current commitments and daily work of civil servants; 
- Final effect indicators or indicators characterizing basic directions of activity of department or authority as a whole, for which a civil servant may have an impact in greater or lesser degree.

Federal Law "On State Civil Service in the Russian Federation" determins that there are following types of indicators:

- Generalized indicators of efficiency and effectiveness of professional performance. that are typical indicators (as a rule characterizing processes and standards), common to many public servants;

- Specific indicators of efficiency and effectiveness of professional performance. Individually set for individual civil servants indicators (usually characterizing final effect and immediate results), related to specific activities of public authority and / or specificity of a public servant activity.

Often subjects of the Federation carried out implementation of performance indicators is in a wrong way. It is an error when public authorities take decision on remuneration of civil servants according to their results and performance without having determined degree of influence on the final result.

The author proposes fundamental approach to accounting results of the work of civil servants on the basis of final performance. At the same time indicators are divided on Process and Scoring indicators according to the international practices. Depending on the taken position, civil servant has indicators of processes and regulations, immediate results, and head managers' efficiency indicators are based on the performance of the final effect, as long as on indicators mentioned above. At the same time the achievement of each indicator is estimated at point measurement. Statement of the problem is as follows:

One need to evaluate the contribution of civil servants based on an assessment of results of their work in the context of indicators of processes and procedures and indicators that reflect the performance.

$\mathrm{A}_{\mathrm{ji}_{\mathrm{j}}}$ - result of the activities of category of servants evaluated by the $\mathrm{i}_{\mathrm{j}}$ indicator;

$\mathrm{j}=\overline{1, \mathrm{n}}$-ordinal number of category of servants

$\mathrm{i}_{\mathrm{j}}=\overline{1, \mathrm{n}_{\mathrm{j}}}$-ordinal number the indicator, which characterizes the result of activities of $\mathrm{j}$ category of servants;

$\alpha_{i_{j}}$-importance of $i_{j}$ indicator of activity results for the $j$ category of servants;

$\sum_{i_{j}=1}^{n_{j}} \alpha_{i_{j}}=1$-condition for balance normalization;

$\alpha_{j}$-importance of different categories of servants;

$\sum_{\mathrm{j}=1}^{\mathrm{n}} \alpha_{\mathrm{j}}=1$-condition for balance normalization;

$\mathrm{A}=\sum_{\mathrm{j}=1}^{\mathrm{n}} \alpha_{\mathrm{j}} \sum_{\mathrm{i}_{\mathrm{j}}=1}^{\mathrm{n}_{\mathrm{j}}} \alpha_{\mathrm{i}_{\mathrm{j}}} \mathrm{A}_{\mathrm{ji}_{\mathrm{j}}}$-the cumulative result of activity of all categories of servants;

$\mathrm{B}_{\mathrm{lk}_{\mathrm{l}}}$ - result of the implementation of project activities by the 1 category of servants on the $\mathrm{k}_{\mathrm{l}}$ process;

$\mathrm{l}=\overline{1, \mathrm{~m}}$-ordinal number of category of servants carrying out activities of the process;

$\mathrm{k}_{\mathrm{l}}=\overline{1, \mathrm{~m}_{\mathrm{l}}}-$ ordinal number of indicator characterizing the process activity of the 1 categories of servants;

$\beta_{\mathrm{k}_{\mathrm{l}}}$-importance of the $\mathrm{k}_{\mathrm{l}}$ indicator of process activity of the 1 category of servants;

$\sum_{\mathrm{k}_{1}=1}^{\mathrm{m}_{1}} \beta_{\mathrm{k}_{1}}=1$-condition for balance normalization;

$\beta_{1}$ - importance of various categories of servants engaged in the process activity;

$\sum_{\mathrm{l}=1}^{\mathrm{m}} \beta_{\mathrm{l}}=1$-condition for balance normalization;

$\mathrm{B}=\sum_{\mathrm{l}=1}^{\mathrm{m}} \beta_{\mathrm{l}} \sum_{\mathrm{k}_{1}=1}^{\mathrm{m}_{1}} \beta_{\mathrm{k}_{1}} \mathrm{~B}_{\mathrm{lk}_{\mathrm{l}}}$-cumulative result of the process activity of servants;

$C=\alpha A+\beta B$-integral indicator that characterizes all types of servants activities;

$\alpha$-importance of effective activities of servants; 
$\beta$-importance of process activities of servants;

$\alpha+\beta=1-$ condition for balance normalization.

The evaluation scale can be made using following components (Table 2).

Table 2. Determination of performance category of employees in executive authorities.

\begin{tabular}{|c|c|}
\hline Performancecategory & Generalperformancelevel \\
\hline "unsatisfactory" & lessthan $50 \%$ \\
\hline "Minimumacceptable" & $51-70 \%$ \\
\hline "Satisfyingtherequirements" & $71-85 \%$ \\
\hline "exceedtherequirements" & $86 \%$ \\
\hline
\end{tabular}

Difficulties in the application of this technique consist, as for all procedures of this kind, the following: it is time-consuming to generate a list of all the necessary performance indicators, set their ratio in evaluation system. However, once conducted analysis of work conditions will identify common indicators and summarize the most essential criteria.

It is possible to make a revision procedure after establishment of the list of indicators.

\section{Discussion}

Review of incentive system of state power authorities in Russia on the basis of scientific literature has identified following features of nature of work and motivation.

The system of state and municipal authority has its own particular motivation features, related primarily to the nature of activities. The peculiarity of work in authorities is high social significance of this work, and as a consequence high role of the individual in the civil servant positions. Stress, high level of responsibility, comprehensive knowledge, professionalism, social competence, high neuro-emotional tension, large proportion of creative component, variety of content are the main components of manager's work as far as the specialist to take the state and municipal offices.

In this connection, special motives to be active are dominating in the motivation of civil servants. According to scientists $[6,10,25]$ employees are primarily concerned with career advancement, size and stability of wages, receiving social benefits. The work of employees is not stimulated by moral encouragement / punishment, salary is noncompetitive and career advancement mechanisms work poorly. Economists estimate wages as the main assessment of employee's contribution tool/ it has motivational (catalytic) function, aimed at increasing interest in the outcome of labor of employee of any socioeconomic system $[7,14,18]$.

The stimulating effect of wages / salaries may vary depending on the set levels of remuneration and compliance of its size with labor contribution. Therefore, stimulating role of wages can be measured by its effectiveness.

Decree of the President of the Russian Federation dated May 7, 2012 № 601 "On the main directions of improving governance" is defining range of topical areas of reform and development of the state civil service in Russian Federation [28]. As part of improving the wages it schedules:

a) Its improvement, taking into account the state of the labor market;

b) Increase in wages of civil servants, due to the real effectiveness of their work;

c) Establishment of a special order of remuneration, depending on achievement of performance indicators of professional activity, as well as establishing common approach to the implementation of giving benefits to government civil servants for performance of especially important and difficult tasks according to results of their work. 
The Russian Federal Law dated July 27, 2004 № 79-FZ "On State Civil Service in the Russian Federation" has defined obligatory presence of performance indicators for all civil servants, which need to be linked with system of motivation.

To implement this law, subjects of Federation attempted to evaluate effectiveness of civil servants activities. However, absence of common approach to the identification of indicators of labor efficiency prompted governments to look for new ways to solve this problem. These findings indicate the need for an objective assessment of labor contribution and creation of a system of motivation, which could consider these factors and features.

The proposed by the authors model will allow to calculate bonus payments on the basis of the identified list of indicators in accordance with requirements of the state.

\section{Conclusion}

In accordance with modern requirements and current trends in the field of payment in the Russian system of state power there is an issue of forming a new remuneration system, which must reconcile results of work of civil servants with their monetary maintenance (wages). Executive bodies of the Yamal-Nenets Autonomous District have also faced this problem. Basing on the survey of civil servants it has been established that on the background of discredited system of career development as one of the incentives for labor wages, the remuneration system set in dependence on results of work and achievement of performance indicators, nowadays is the main motive of the majority of employees. This confirms once again that it is necessary to improve the market mechanisms of motivation in the organs of state power.

Widely discussed in the scientific community issue has great interest of researchers for several reasons: firstly, there is still no set list of required performance indicators, and secondly, there is no mechanism linking performance indicators with payment. In this connection, authors of the article present one of the possible ways of formation the wage system, which takes into account the most important approach for employees in terms of different indicators - their dividing into process indicators and outcome indicators.

\section{References}

1. J.M. Stritch, R.K. Christensen, International Journal of Manpower 37-5, 840-858 (2016) DOI: 10.1108/IJM-12-2014-0249

2. D. Navot, Y. Reingewertz, N. Cohen, Administration and Society 48-5, 580-601 (2016) DOI: $10.1177 / 0095399715623313$

3. M. TepePublic Management Review 18-4, 508-538 DOI: $10.1080 / 14719037.2015 .1014396$

4. A. Kopytova, Procedia Engineering 165, 1132 (2016) DOI: 10.1016/j.proeng.2016.11.830

5. G.S. Armashova-Telnik, Actual problems of economics and management 4(8), 71-74 (2015)

6. N.L. Zakharov, Social regulators of the Russian civil servant (Moscow, 2002)

7. N.S. Zotkina, Finances and Credit 48 (480), 21-28 (2011)

8. E.V. Vasiliev, V.D. Vasilyev, Economics and Management - 2015, 240-250 (2015)

9. E.I. Vasileva, Social life and power 2, 11-14 (2010) 
10. E.V. Gorshkova, Improvement of the system of motivation of labor of state civil servants: theoretical and methodical aspects (Econ. Sciences, Moscow, 2010)

11. E.A. Mitrofanova, Personnel and intellectual resources management in Russia 2, 36-41 (2014)

12. Information on the formation of indicators for assessing the effectiveness and effectiveness of professional performance of civil servants, http://www.pfo.ru/?id=30513

13. A.I. Kazannik, Bulletin of Omsk University 4 (33), 35-43 (2012)

14. A.V. Kopytova, Exchange of intellectual property 3 (XIV), 31-37 (2015)

15. B. Liu, J.L. Perry, Review of Public Personnel Administration 36-1, 4-30 (2016) DOI: $10.1177 / 0734371 X 14549672$

16. J. Yeo, International Journal of Public Administration 39-3, 216-225 (2016) DOI: $10.1080 / 01900692.2015 .1004083$

17. M.S. Gusarova, A.V. Kopytova, Bulletin of Omsk University 4,14-22 (2014)

18. N.S. Zotkina, A.V. Kopytova, Economics and entrepreneurship 12-2(53-2),714-719 (2014)

19. L.T. Tuan, International Journal of Public Sector Management 29-1, 91-108 (2016) DOI: 10.1108/IJPSM-06-2015-0112

20. S. De Simone, G. Cicotto, R. Pinna, L. Giustiniano, Management Decision 54-7, 1569-1594 (2016) DOI: 10.1108/MD-02-2016-0072

21. J.W. Campbell, T. Im, Public Personnel Management 45-3, 308-330 (2016) DOI: $10.1177 / 0091026016664899$

22. A.R. Mukhametgalieva, Conference proceedings, 614-617 (2015)

23. Z.S. Pashayeva, S.M. Kalabekova, Management of the economic and social systems of the region, 208-214 (2015)

24. A.V. Selyuk, A.V. Kuprin, S.A. Bardasov, Management of innovative projects (Tyumen, 2015)

25. E. Chernova, Kadrovik. Labor law for the personnel officer, 3 (2009)

26. V.I. Sharin,Izvestia Ural State University of Economics and Management 3 (53), 62-68 (2014)

27. Decree of the President of the Russian Federation of 07.05.2012 No. 601 "On the main directions of improving the system of public administration", http://www.rg.ru/2012/05/09/gosupravlenie-dok.html (2014)

28. Presidential Decree dated 07.05.2012 № 601 "On the main directions of improving governance», http://www.rg.ru/2012/05/09/gosupravlenie-dok.html (2014)

29. Federal Law on the Civil Service of the Russian Federation No. 79-FZ of July 27, https://legalacts.ru/doc/79_FZ- O-gosudarstvennoj-grazhdanskoj-sluzhbe(2014) 